\title{
APLIKASI MARKETPLACE BATIK MADURA DI SENTRA BATIK PASAR 17 AGUSTUS PAMEKASAN
}

\author{
Ubaidi, Nindian Puspa Dewi \\ Program Studi Informatika, Universitas Madura \\ Jl. Raya Panglegur KM. 3,5 Pamekasan Madura \\ ubed@unira.ac.id, nindianpd@unira.ac.id
}

\begin{abstract}
August 17 Market is one of the largest traditional markets in Pamekasan. This market is also well known as a batik market, which is the center of Madura Batik sales. In this market, traffic jams often occur, making it difficult for batik buyers to visit the batik market, which is located in the middle of the market. For this reason, it is necessary to create a marketplace for selling Batik Madura on August 17 Market. This Batik Sales Marketplace application is designed with Extreme Programming. This Marketplace application is made with web and mobile-based so it can be accessed anywhere and anytime without having to market. Different from the previous application, to make it easier for visitors/buyers, besides being equipped with a short message feature, this application is also equipped with a seller location plan. That way, visitors/buyers can easily find seller locations if they want to shop offline. This feature is helpful in efficiency when searching. With this application, it can expand the marketing and promotion of Batik Madura as one of the cultural treasures of Madura.
\end{abstract}

Keywords - Marketplace, Market, Batik, Batik Madura, Pamekasan.

Abstrak - Pasar 17 Agustus merupakan salah satu pasar tradisional terbesar di Pamekasan. Selain sebagai pasar tradisional pada umumnya, pasar ini juga terkenal sebagai pasar batik yang menjadi pusat penjualan Batik Madura. Di pasar ini sering terjadi kemacetan sehingga menyulitkan para pembeli batik untuk mengunjungi pasar batik yang lokasinya dibagian tengah pasar. Karena itulah, perlu dibuat sebuah marketplace penjualan Batik Madura di Pasar 17 Agustus Pamekasan. Aplikasi Marketplace Penjualan Batik ini dirancang dengan Metode Agile Software Development jenis Extreme Programming. Aplikasi Marketplace ini dibuat dengan berbasis web dan mobile sehingga dapat diakses dimana saja dan kapan tanpa harus mengunjungi Pasar 17 Agustus Pamekasan. Berbeda dari aplikasi sebelumnya, untuk memudahkan pengunjung/pembeli, aplikasi ini selain dilengkapi dengan fitur pesan singkat juga dilengkapi dengan denah lokasi pelapak. Dengan begitu, pengunjung/pembeli dapat dengan mudah menemukan lokasi pelapak jika ingin berbelanja secara offline. Fitur ini sangat membantu dalam efisiensi waktu saat melakukan pencarian. Dengan adanya aplikasi ini maka dapat memperluas pemasaran dan promosi Batik Madura sebagai salah satu kekayaan budaya Madura yang banyak diminati oleh masyarakat di luar Madura.

Kata Kunci - Marketplace, Pasar, Batik, Batik Madura, Pamekasan.

\section{PENDAHULUAN}

Di era saat ini, perkembangan teknologi informasi adalah sesuatu yang tidak bisa dihindari. Hampir semua lini kehidupan sudah beralih menggunakan teknologi informasi untuk menuju kearah digital, salah satunya untuk pengembangan daerah [1][2][3]. Bukan tanpa sebab, penggunaan teknologi memang sangat memudahkan dalam pengolahan dan pengaksesan data. Pemanfaatan teknologi informasi ini sangat erat hubungannya dengan penggunaan internet. Menurut APJII (Asosiasi Penyelenggara Jasa Internet Indonesia), pada Tahun 2018 jumlah pengguna Internet di Indonesia mencapai 171,17 juta pengguna dari penduduk Indonesia yang berjumlah 264, 16 juta jiwa [4]. Dan jumlah ini terus meningkat seiring dengan bertambahnya pelayanan internet yang masuk ke daerah pelosok-pelosok desa di Indonesia.

Pemanfaatan teknologi yang paling berkembang adalah dalam dalam bidang ekonomi [5]. Salah satunya adalah Marketplace. Pada dasarnya, marketplace hampir sama dengan pasar tradisional yang merupakan tempat bertemunya banyak penjual dan pembeli. Hanya saja, penjual dan pembeli tidak perlu lagi bertemu secara langsung dengan tetap bisa melakukan transaksi jual beli [6]. Selain itu, marketplace dapat meningkatkan promosi penjualan karena dapat diakses darimana saja dan kapan saja. Sehingga secara langsung maupun tidak langsung dapat meningkatkan jumlah penjualan. Contoh beberapa marketplace yang cukup terkenal yaituTokopedia, Shopee dan Blibli.

Penelitian tentang hal ini sudah banyak dilakukan seperti, Perancangan Dan Pengembangan Marketplace Jual Beli Buku Bekas Pada Startup Gebbuk Berbasis Mobile [7], Analisis Sistem E-Commerce Pada Perusahaan Marketplace Mobile Shopee Indonesia [8], Aplikasi Online Marketplace pada PT.XYZ di Surabaya [9], E-Commerce Berbasis Marketplace dalam Upaya Mempersingkat Distribusi Penjualan Hasil Pertanian [10]. Ada juga penelitian tentang marketplace yang menyediakan layanan jasa seperti Pengembangan Aplikasi Marketplace untuk Jasa 
Konfeksi [11] dan Perancangan Aplikasi Marketplace Jasa Percetakan Berbasis Website [12].

Pasar 17 Agustus merupakan salah satu pasar terbesar di Pamekasan, bahkan merupakan pasar batik tulis terbesar di Asia. Selain sebagai pasar tradisional pada umumnya, pasar ini juga terkenal sebagai pasar batik yang menjadi pusat penjualan Batik Madura. Pasar 17 Agustus Pamekasan ini memiliki hari pasaran yaitu pada hari minggu dan kamis. Pada dua hari tersebutlah biasanya para pedagang batik menjajakan batiknya. Selain penjualan batik, pada hari pasaran juga dimanfaatkan penjual unggas dan hewan ternak untuk berjualan. Penjual unggas dan kambing ini biasanya berjualan dipinggir jalan dan sekitar pintu masuk pasar. Hal ini selain menimbulkan kemacetan, juga menyulitkan para pembeli batik untuk mengunjungi pasar batik yang lokasinya dibagian tengah pasar. Akhirnya pembeli terpaksa harus berdesak-desakan karena hanya pada dua hari ini banyak penjual batik dari berbagai daerah yang membuka lapak di Pasar 17 Agustus Pamekasan. Selain itu, pembeli seringkali mengalami kesulitan untuk mencari penjual yang menjual batik sesuai yang diinginkan. Banyaknya penjual batik yang menjual batik dengan berbagai macam harga dan motif mengakibatkan proses pencarian menjadi lebih lama karena pembeli harus mengunjungi satu persatu penjual sampai menemukan batik yang diinginkan. Kejadian yang seperti itu sangat melelahkan dan membuang waktu.

Berdasarkan latar belakang di atas, perlu rasanya untuk membuat sebuah marketplace Pasar 17 Agustus untuk penjualan Batik Madura. Dengan marketplace, selain dapat memudahkan penjual maupun pembeli untuk melakukan transaksi, juga dapat memperluas pemasaran dan promosi Batik Madura. Apalagi Batik Madura merupakan salah satu kekayaan budaya Madura yang banyak diminati oleh masyarakat di luar Madura karena ciri khasnya yang memiliki warna berani dan motif beraneka ragam. Terbukti, pembelinya pun tidak hanya berasal dari kalangan Masyarakat Pamekasan, tapi juga berasal dari luar kota bahkan turis mancanegara.

Adapun penelitian tentang penjualan batik sudah pernah dilakukan antara lain, Analisa dan Perancangan Sistem Informasi Penjualan Online (E-Commerce) pada CV Selaras Batik Menggunakan Analisis Deskriptif [13], E-Marketplace Batik [14] dan Pemanfaatan E-Commerce Dalam Peningkatan Pemasaran di UMKM Grosir Batik Tasikmalaya [15].

Berbeda dengan penelitian e-marketplace sebelumnya, aplikasi marketplace ini selain hanya dapat digunakan bagi penjual batik di Pasar 17 Agustus Pamekasan yang merupakan pasar batik tulis terbesar di Asia, juga menyediakan fasilitas untuk menunjukan lokasi pelapak batik yang ingin dikunjungi pembeli. Dengan begitu dapat membantu pembeli jika ingin melihat langsung batik yang ingin dibelinya. Aplikasi juga dibuat berbasis website untuk admin pasar dan versi mobile untuk memudahkan pelapak dan pembeli dalam mengakses aplikasi. Aplikasi ini juga berperan sekaligus sebagai sistem informasi bagi admin pasar, sehingga admin pasar selain memiliki data pelapak batik di setiap los/blok juga mengetahui perkembangan penjualan batik di Pasar 17 Agustus Pamekasan.

\section{METODE PENELITIAN}

Aplikasi Marketplace Penjualan Batik ini akan dirancang dengan Metode Agile Software Development jenis Extreme Programming (XP) [16]. Metode pengembangan ini meliputi planning, design, implementation/coding dan testing. Secara umum metode pengembangan XP dapat dilihat pada Gambar 1 berikut ini.

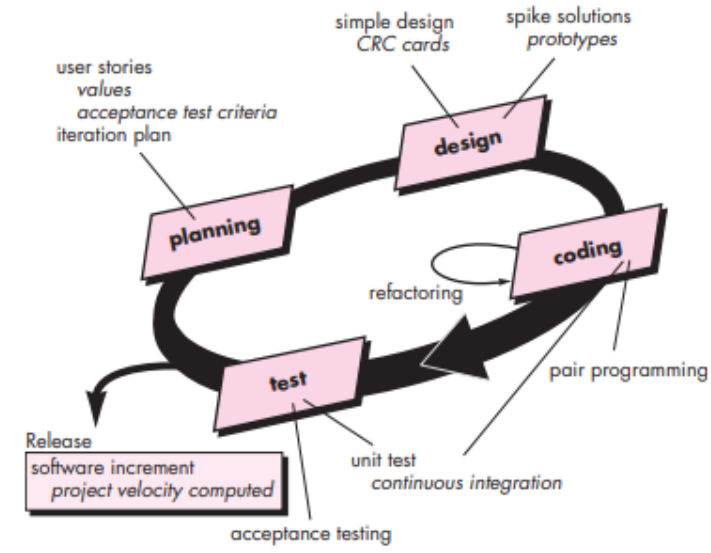

Gambar 1. Proses Extreme Programming (XP)

1. Perencanaan

Pada tahapan ini dikumpulkan kebutuhan awal pengguna atau dalam XP disebut user stories. Pada tahapan penelitian ini wawancara dilakukan secara langsung kepada para pengguna sistem yaitu ketua pasar 17 Agustus Pamekasan, beberapa pelapak dan pembeli Batik Madura. Seperti yang telah disebutkan sebelumnya, marketplace yang akan dibuat memiliki fitur yang dapat menunjukkan lokasi pelapak di dalam pasar, maka dilakukan wawancara dengan ketua pasar terkait dengan proses penataan dan denah dari los/blok batik di Pasar 17 Agustus Pamekasan. Sedangkan dengan pelapak, wawancara dilakukan dengan menanyakan seperti macam jenis dan corak Batik Madura yang dijual, harga, serta proses transaksi penjualan Batik Madura yang selama ini terjadi. Kepada pembeli juga ditanyakan apa saja keluhan mereka saat berbelanja Batik Madura di Pasar 17 Agustus Pamekasan. Pertanyaan juga diajukan seputar sistem dan fitur yang perlu dibuat sehingga dapat membantu para pengguna. Pada tahapan ini juga mengumpulkan data yang dibutuhkan seperti denah pasar untuk penjualan 
batik, jenis dan corak Batik Madura serta blok tempat para pelapak menawarkan dagangannya.

2. Analisa dan Perancangan Sistem

Setelah melakukan wawancara, langkah selanjutnya adalah analisa dan perancangan sistem. Analisa sistem dibagi menjadi analisa user dan analisa input. Sedangkan perancangan sistem pada penelitian ini nantinya digambarkan dengan model UML berupa use case diagram, activity diagram, dan sequence diagram [17][18]. Desain disini merupakan representasi dari sistem guna mempermudah dalam membangun aplikasi marketplace.

3. Pembuatan Aplikasi

Tahap selanjutnya adalah membuat aplikasi marketplace. Marketplace ini dibuat dengan berbasis web untuk admin dan mobile untuk pelapak dan pembeli/pengunjung.

4. Evaluasi dan Pengujian Sistem

Setelah aplikasi marketplace dibangun maka langkah selanjutnya adalah melakukan pengujian dan evaluasi sistem. Ujicoba modul sendiri dilakukan beberapa kali sambil lalu dievaluasi. Setelah sistem selesai maka dilakukan pengujian sistem. Metode pengujian sistem pada penelitian ini menggunakan System Usability Scale (SUS) [16]. Instrumen pengujian yang digunakan sesuai dengan instrumen pada pengujian SUS dengan koresponden yaitu admin pasar, pelapak batik dan pengunjung/pembeli.

\section{HASIL DAN PEMBAHASAN}

Setelah dilakukan observasi lapangan dan wawancara terhadap kepala pasar, pelapak dan sejumlah orang yang pernah melakukan pembelian di Sentra Batik Pasar 17 Agustus maka langkah pertama yang dilakukan adalah pengembangan sistem dengan menggunakan UML. Setelah perancangan sistem selesai maka langkah selanjutnya adalah implementasi dan pengujian sistem.

\section{A. Perancangan Sistem}

Perancangan sistem pada penelitian ini berupa analisa user, use case diagram, activity diagram, dan sequence diagram. Desain disini merupakan representasi dari sistem guna mempermudah dalam membangun aplikasi marketplace.

1. Analisa User

Dalam aplikasi marketplace penjualan batik di pasar 17 Agustus Pamekasan berbasis mobile terdapat 3 aktor/user yang berinteraksi dalam aplikasi ini, untuk lebih jelasnya bisa dilihat dalam Table 1 .

Tabel 1. Analisa User

\begin{tabular}{|c|c|l|}
\hline No. & $\begin{array}{c}\text { User/ } \\
\text { Aktor }\end{array}$ & \multicolumn{1}{c|}{ Keterangan } \\
\hline 1. & $\begin{array}{l}\text { Admin } \\
\text { Market }\end{array}$ & $\begin{array}{l}\text { User ini merupakan admin dari } \\
\text { aplikasi marketplace yang } \\
\text { mengontrol semua aktivitas di sistem } \\
\text { ini }\end{array}$ \\
\hline
\end{tabular}

\begin{tabular}{|c|c|l|}
\hline No. & $\begin{array}{c}\text { User/ } \\
\text { Aktor }\end{array}$ & \multicolumn{1}{c|}{ Keterangan } \\
\hline 2. & Pelapak & $\begin{array}{l}\text { User ini merupakan penjual } \\
\text { barang/batik, user ini yang mengelola } \\
\text { item batik, mengontrol dana } \\
\text { mengelola barang masuk serta keluar. }\end{array}$ \\
\hline 3. & Pembeli & $\begin{array}{l}\text { User ini merupakan pengguna front- } \\
\text { end aplikasi marketplace, dimana } \\
\text { melihat dan mencari barang/batik } \\
\text { serta lokasi los/blok batik. }\end{array}$ \\
\hline
\end{tabular}

2. Use Case Diagram

Ada 3 use case diagram dalam penelitian ini yaitu, use case diagram admin market, pelapak dan pembeli. Gambar 2 merupakan use case diagram untuk admin market. Yang dimaksud admin market dalam sistem ini adalah kepala pasar yang dapat melakukan proses kelola user, kelola pelapak, kelola pembeli, dan dapat melakukan proses monitoring.

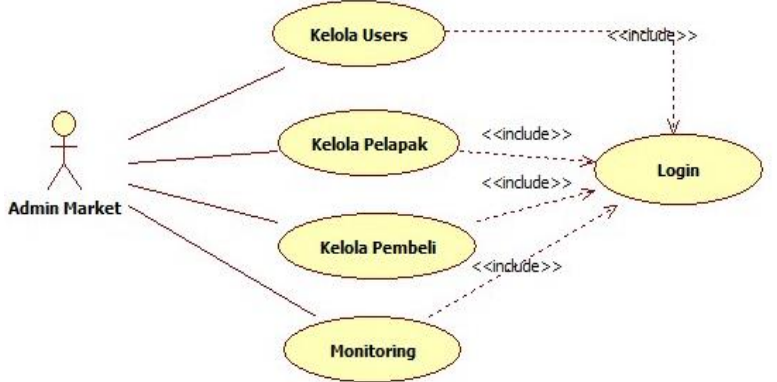

Gambar 2. Use case diagram Admin Market

Selanjutnya untuk use case diagram pelapak/penjual ditunjukkan pada Gambar 3. Pelapak atau penjual Batik Madura dapat melakukan kelola item atau batik, menerima pemesanan, monitoring dan menerima/mengirim pesan singkat melalui aplikasi Whatsapp.

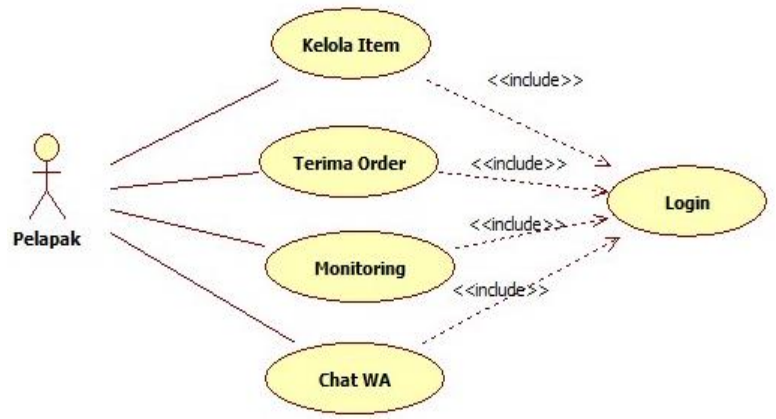

Gambar 3. Use case diagram Pelapak

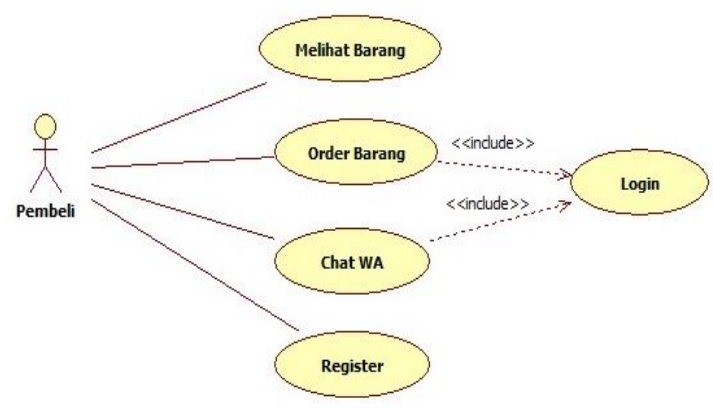

Gambar 4. Use case diagram Pembeli 
Pembeli maupun calon pembeli dapat melakukan pencarian batik atau melihat secara detail batik yang ditampilkan di dalam aplikasi. Sebelum melakukan transaksi pembelian Batik, Pembeli harus melakukan register terlebih dahulu jika belum memiliki akun atau login jika sudah memiliki akun. Sama halnya dengan pelapak, pembeli dapat menerima/mengirim pesan singkat melalui aplikasi Whatsapp. Use case diagram untuk pembeli dapat dilihat pada Gambar 4.

3. Activity Diagram

Untuk menggambarkan aliras proses dalam aplikasi marketplace ini digunakan beberapa Activity Diagram yaitu activity diagram admin, activity diagram pelapak, activity diagram pembeli dan activity diagram order barang.

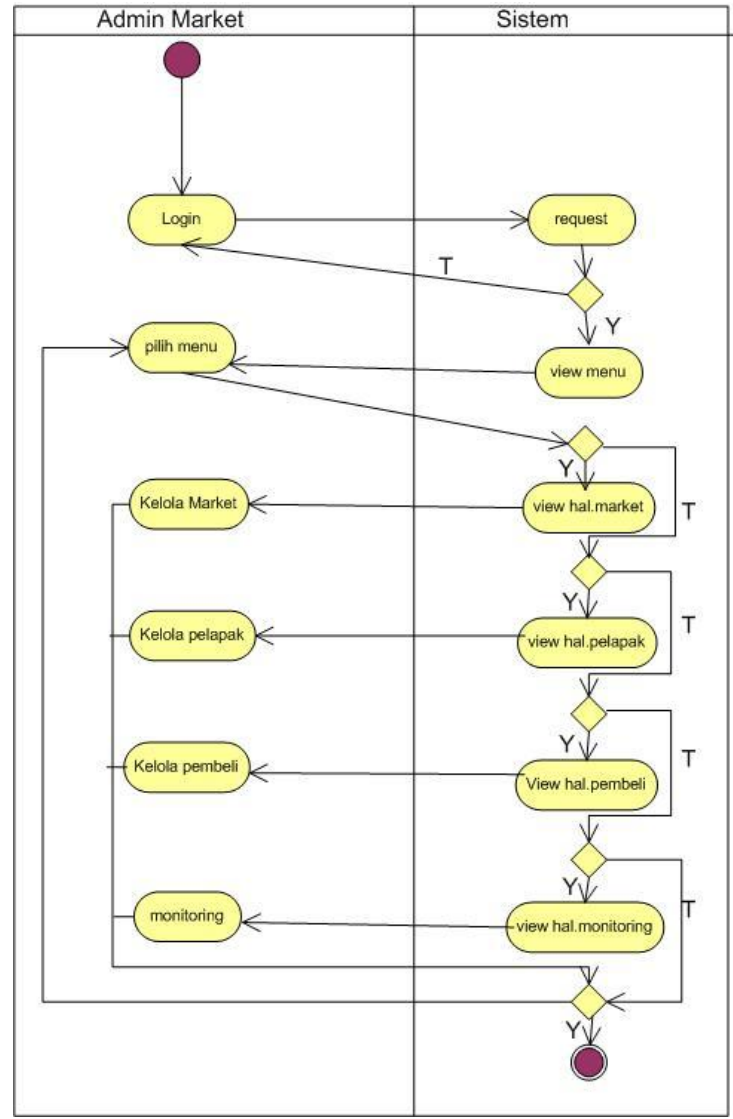

Gambar 5. Activity Diagram Admin

Activity diagram admin ditunjukkan pada Gambar 5 menjelaskan aktifitas admin market/admin pasar. Jika login berhasil, aplikasi akan mengarahkan ke menu-menu yang terdapat pada aplikasi seperti kelola market, dan kelola pelapak. Kelola market merupakan kegiatan admin untuk menentukan nama los/blok di area penjualan Batik Madura. Kelola pelapak meliputi kegiatan mendaftarkan pelapak baru, memasukkan nama lapak/toko dan letak lapak dalam los/blok.

Gambar 6 menjelaskan tentang aktivitas pelapak atau penjual Batik Madura. Setelah berhasil login, pelapak dapat melakukan kelola data batik yang akan ditawarkan, mengelola orderan, monitoring dan mengirimkan pesan whatsapp. Dalam penelitian ini pelapak harus melakukan pendaftaran ke admin market. Jadi, hanya mereka yang secara resmi menjual di Sentra Batik Pasar 17 Agustus Pamekasan yang bisa menggunakan aplikasi ini.

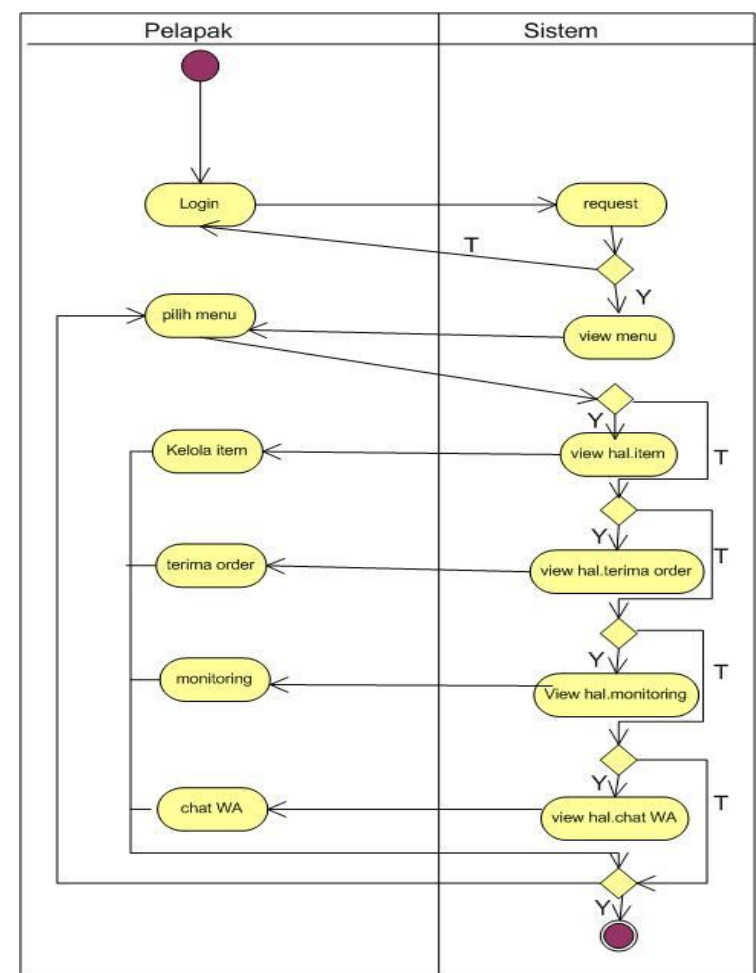

Gambar 6. Activity Diagram Pelapak

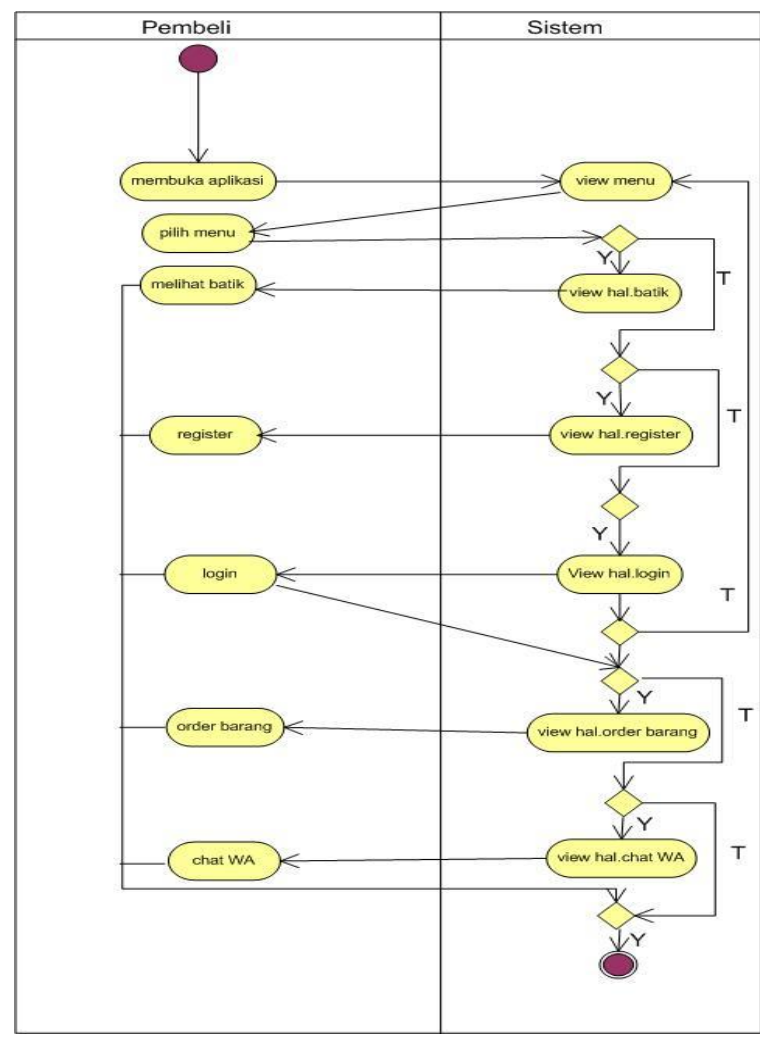

Gambar 7. Activity Diagram Pembeli/Pengunjung 
Selanjutnya Gambar 7 menjelaskan tentang aktifitas pembeli dan pengunjung ketika menggunakan aplikasi. Aplikasi akan menampilkan menu-menu yang ada.

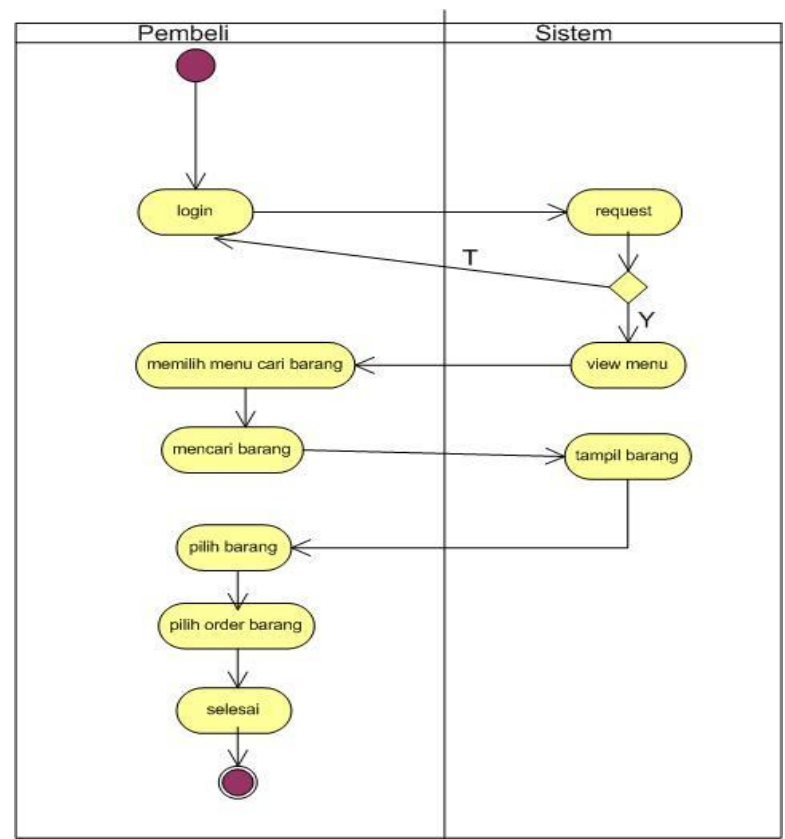

Gambar 8. Activity Diagram Pembelian Batik

Untuk pengunjung yang hanya ingin melihat atau mencari batik tidak perlu melakukan login terlebih dahulu. Tetapi jika ingin melakukan pemesanan, maka harus mendaftar terlebih dahulu sebagai pembeli dengan cara memilih menu register. Setelah berhasil login, pengunjung/pembeli bisa melakukan order barang dan mengirimkan pesan singkat melalui fasilitas Whatsapp kepada pelapak untuk bertanya langsung tentang Batik Madura yang ingin dibeli.

Activity diagram pembelian menjelaskan tentang aktifitas pembeli yang ingin melakukan pembelian batik. Untuk melakukan pembelian batik, pembeli harus melakukan login terlebih dahulu. Jika login berhasil, maka aplikasi akan menampilkan menu yang ada. Pembeli dapat memilih dan mencari batik yang mereka inginkan dan melakukan pembelian. Activity diagram untuk pembelian batik dapat dilihat pada Gambar 8.

\section{Squence Diagram}

Sequence diagram menjelaskan secara detail urutan proses yang dilakukan oleh bagian yang terlibat di dalam sistem sampai mencapai tujuan dari use case diagram. Sequence diagram input data batik menjelaskan tentang proses yang dapat dilakukan oleh pelapak atau penjual. Pelapak akan dihadapkan pada form kelola barang/batik dan lainnya yang dibutuhkan untuk menambahkan item batik. Setelah itu, inputan barang tersebut akan diproses. Pelapak dapat juga dapat memperbaharui item batik di form input barang. Setelah pelapak memperbaharui item batik, pelapak dapat melihat perbaharuan item batik tersebut. Sequence diagram input data batik dapat dilihat pada Gambar 9.

Sequence diagram pembelian batik menjelaskan tentang proses-proses yang akan dilakukan oleh pembeli. Pembeli dapat melihat dan mencari barang pada form order barang. Sistem dapat menampilkan beberapa tampilan barang-barang yang ada. Pembeli juga dapat memilih barang yang akan dipesan pada form order barang. Sequence diagram pembelian batik dapat dilihat pada Gambar 10.

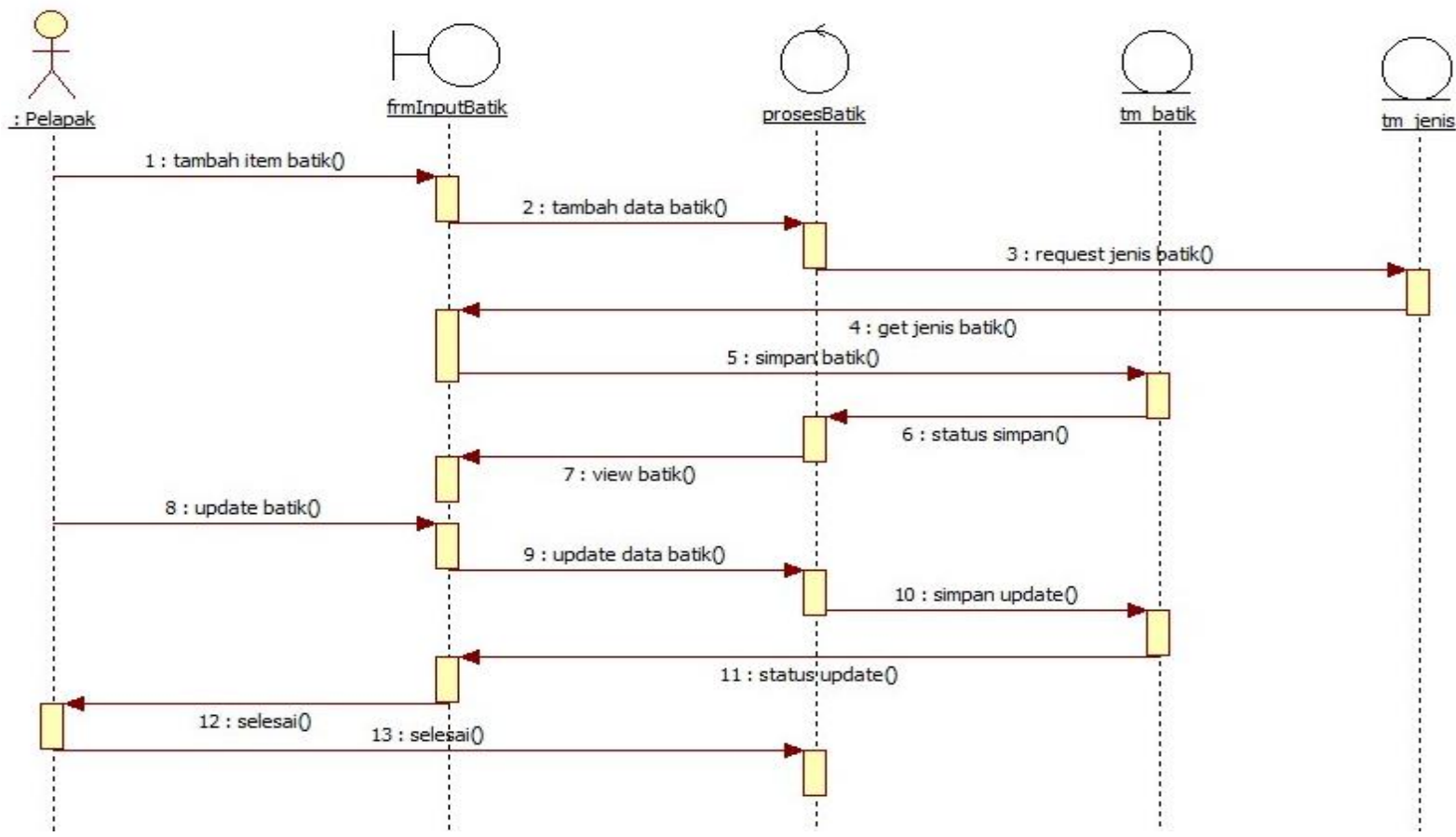

Gambar 9. Sequence Diagram Input Data Batik 


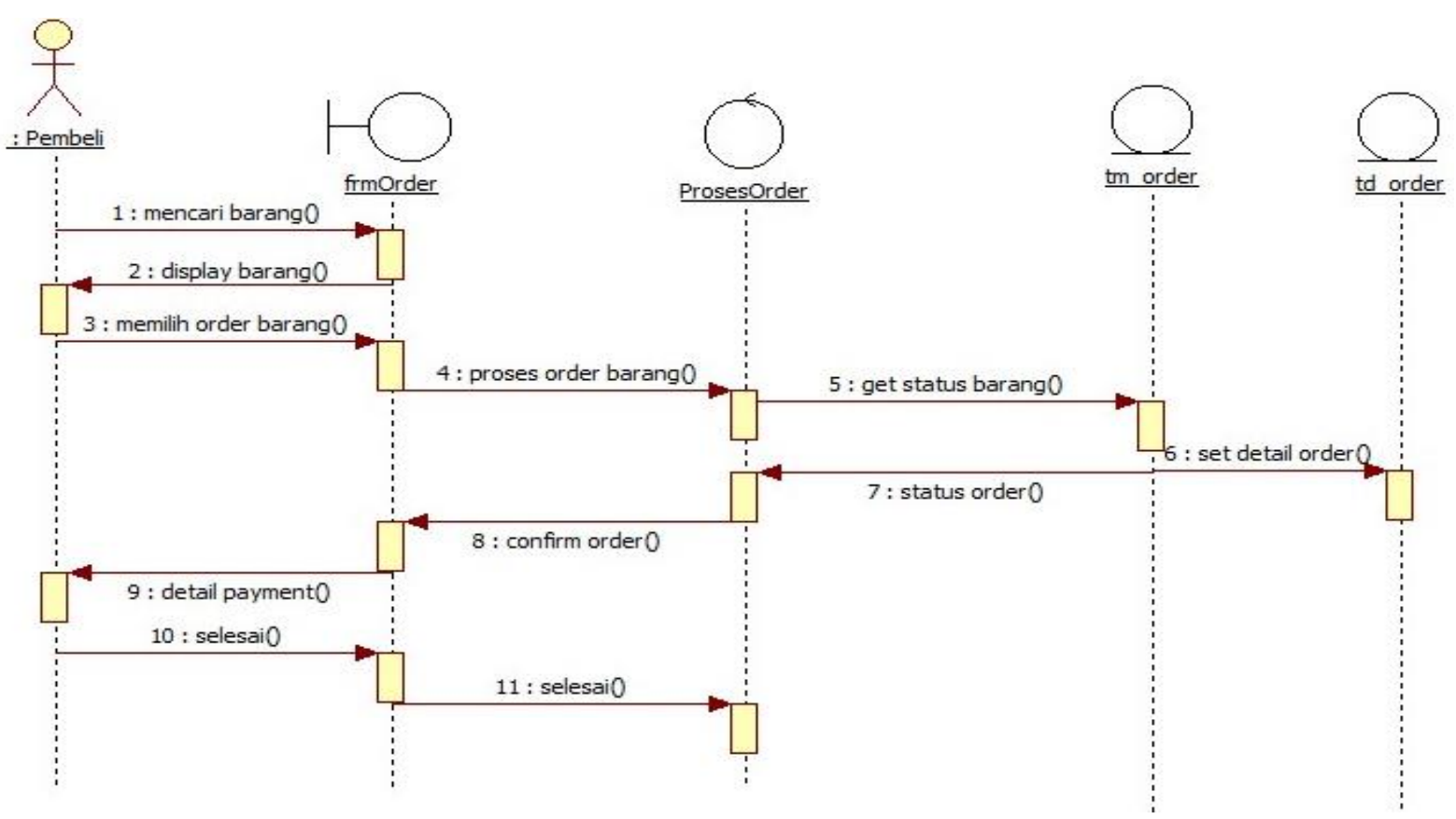

Gambar 10. Sequence Diagram Pembelian Batik

Pembeli juga dapat melakukan input ulasan atau pertanyan tentang barang atau batik yang dilihat ataupun yang sudah dibeli. Kemudian, sistem akan memproses ulasan tersebut dan tersimpan dalam ulasan. Selanjutnya pelapak atau penjual menerima ulasan tersebut dan kemudian pelapak merespon ulasannya, maka sistem akan menampilkan hasil respon ke pembeli. Sequence diagram untuk ulasan barang dapat dilihat pada Gambar 11.

Admin melakukan input data - data pelapak ke modul pelapak beserta inputan lainnya. Setelah itu data tersebut disimpan, kemudian sistem akan mengecek apakah data yang diinputkan valid. Setelah sistem menyatakan valid maka data akan tersimpan dengan status sukses. Begitu juga untuk proses update data pelapak, perubahan tersebut akan diproses, dan perubahan tersebut akan tersimpan pada data tm_lapak. Admin akan mendapatkan status bahwa perubahan data tersebut telah berhasil tersimpan. Proses ini ditunjukkan dalam Sequence diagram lapak yang ditunjukkan pada Gambar 12.

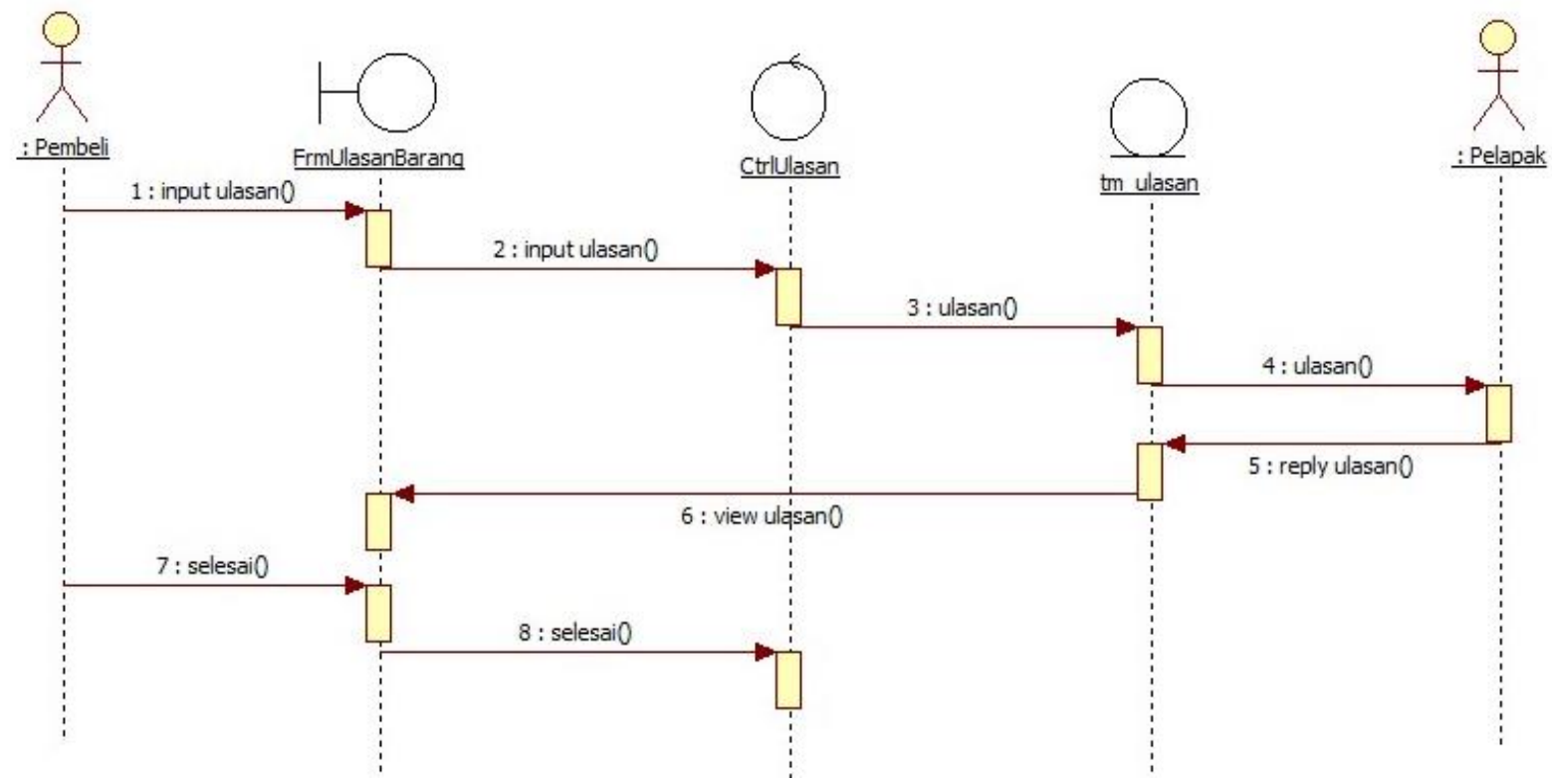

Gambar 11. Sequence Diagram Ulasan Barang 


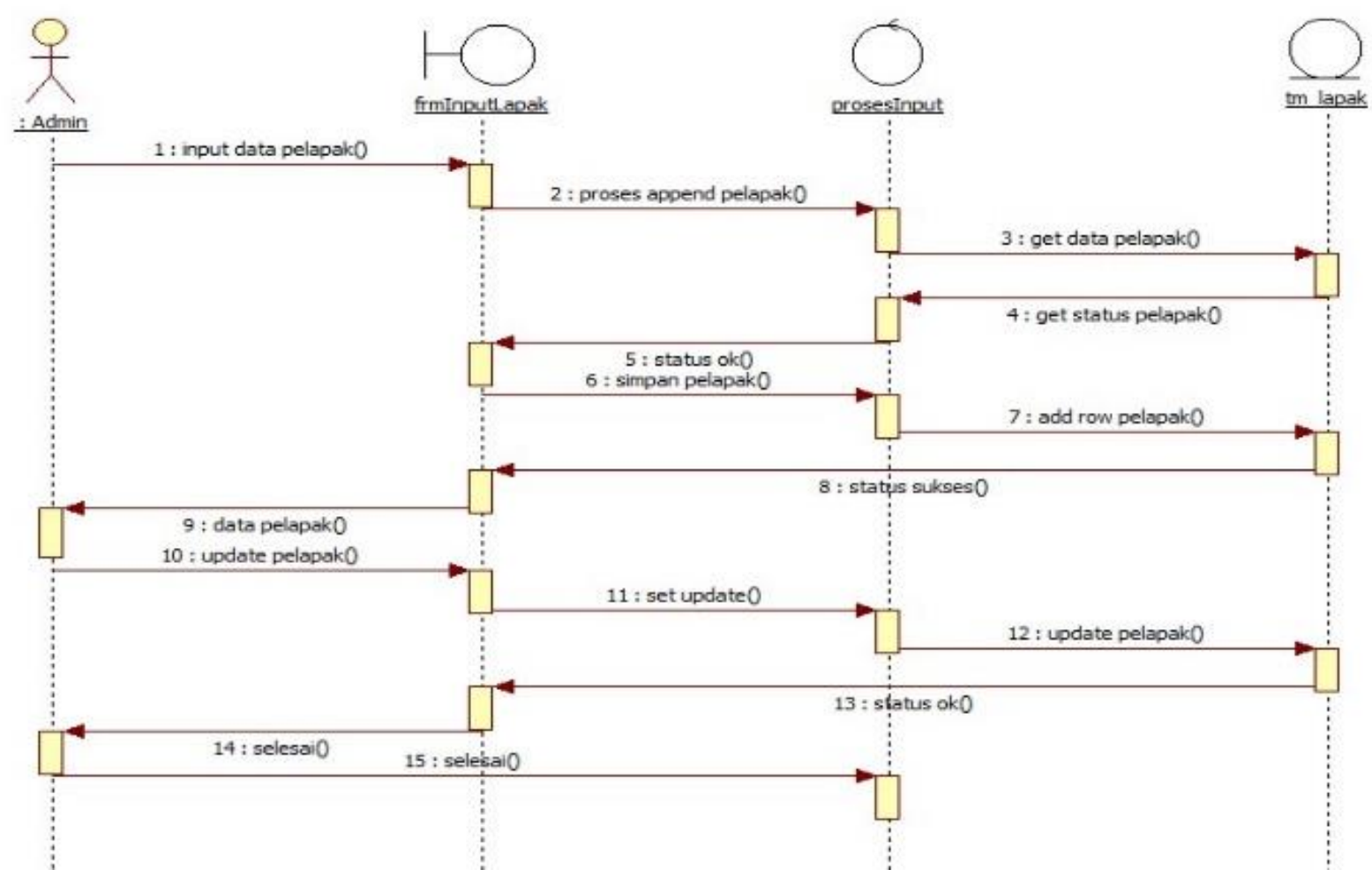

Gambar 12. Sequence Diagram Lapak

5. Perancangan Database

Rancangan basis data untuk aplikasi marketplace penjualan batik di pasar 17 Agustus Pamekasan berbasis mobile ditunjukkan dengan membuat Class Diagram pada Gambar 13.

Ada 6 tabel master yang digunakan yaitu tm_jenis, tm_batik, tm_lapak, tm_user, tm_ulasan, tm_order dan 1 tabel detail yaitu td_order.

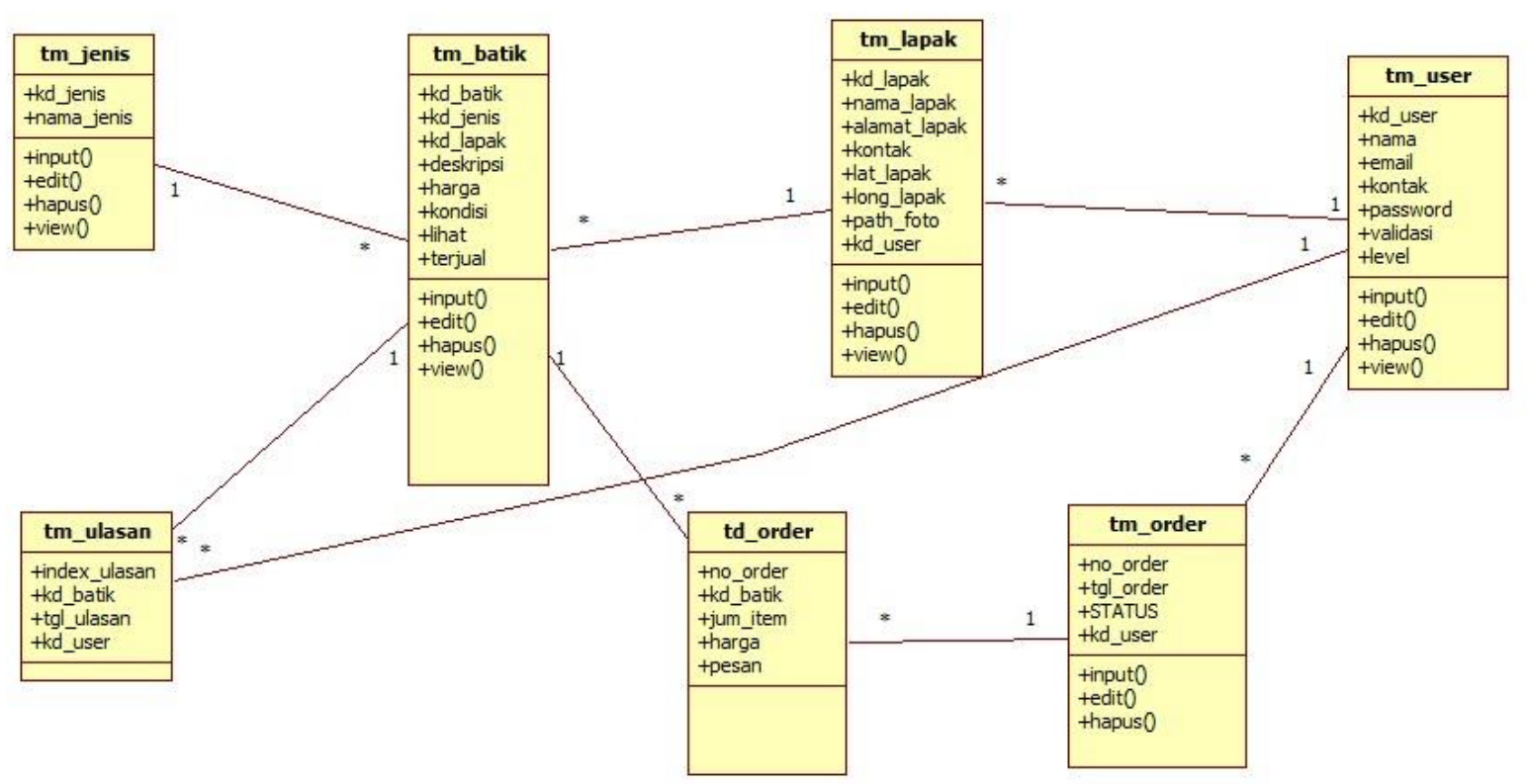

Gambar 13. Class Diagram 


\section{B. Implementasi Sistem}

Aplikasi marketplace dibuat dalam dua model interface yaitu berbasis web dan mobile. Untuk admin market menggunakan tampilan yang berbasis web. Sedangkan untuk pelapak dan pengunjung/pembeli menggunakan tampilan berbasis mobile.

\section{Halaman Admin Market}

Bagian yang paling penting dari admin market adalah melakukan kelola data pelapak. Untuk bisa menjadi pelapak di aplikasi marketplace ini, pelapak harus mendaftarkan diri melalui admin market yang merupakan kepala pasar. Admin market akan melakukan input data pelapak dimulai dari nama lapak, data diri pelapak sampai dengan blok tempat pelapak menjajakan dagangannya. Dari sini juga pelapak dapat memperoleh username dan password. Selain itu, admin market juga dapat menambahkan petugas pasar lainnya untuk menjadi admin market dan membantu dalam pengelolaan data. Adapun tampilan untuk tambah data lapak dan user (admin) dapat dilihat pada Gambar 14 dan Gambar 15.

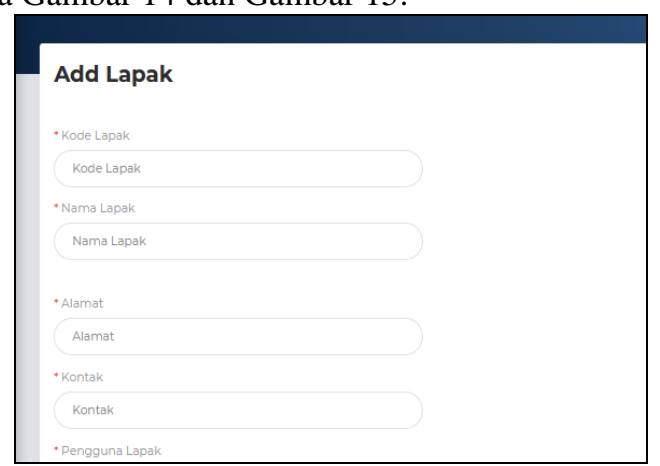

Gambar 14. Halaman Tambah Lapak

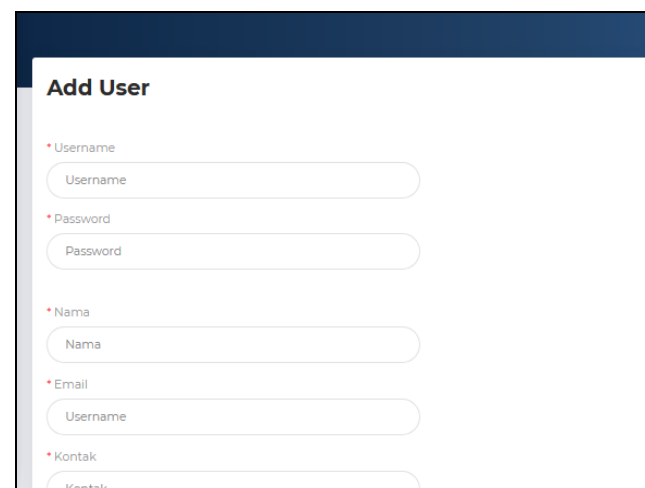

Gambar 15. Halaman Tambah User (Admin) Baru

2. Halaman Pelapak dan Pengunjung/Pembeli

Sebelum login, baik pelapak maupun pengunjung dapat melihat katalog batik yang ditawarkan dalam marketplace. Halaman ini adalah halaman pertama form splash screen selesai. Tampilan katalog batik dapat dilihat pada Gambar 16. Pengunjung dapat melihat detail batik dengan menekan gambar batik yang ingin dilihat detailnya. Pada halaman ini ditampilkan harga, stok dan ukuran batik.

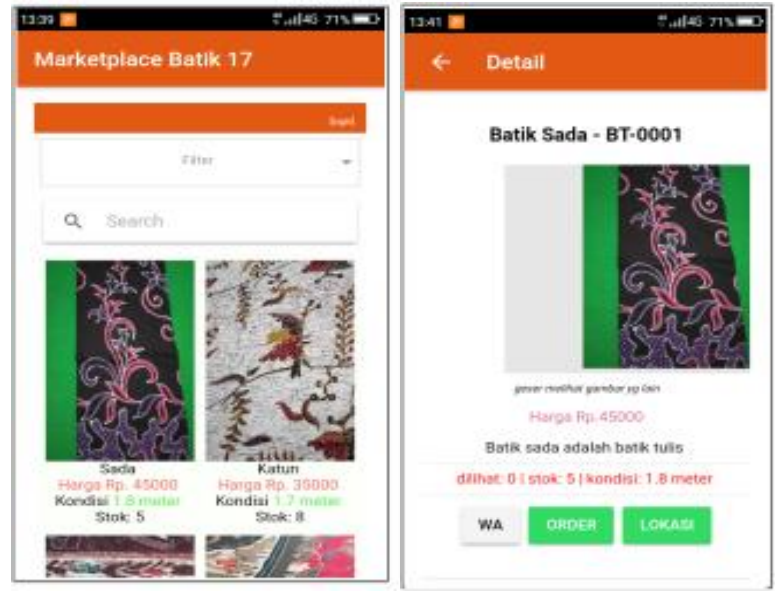

Gambar 16. Halaman Katalog Batik

Jika pembeli sudah melakukan login maka pembeli dapat langsung mengirim pesan singkat melalui Whatsapp dapat melakukan order batik. Jika pembeli menekan tombol order, maka akan tampil form untuk menginputkan jumlah batik yang ingin dibeli. Setelah melakukan order batik, pembeli harus menunggu konfirmasi terlebih dahulu dari pelapak. Setelah dikonfirmasi, maka pembeli diminta melakukan upload bukti pembayaran untuk mengirim bukti pembayaran sebagai tanda bahwa pembeli telah melunasi pembayaran. Form order batik dapat dilihat pada Gambar 17.

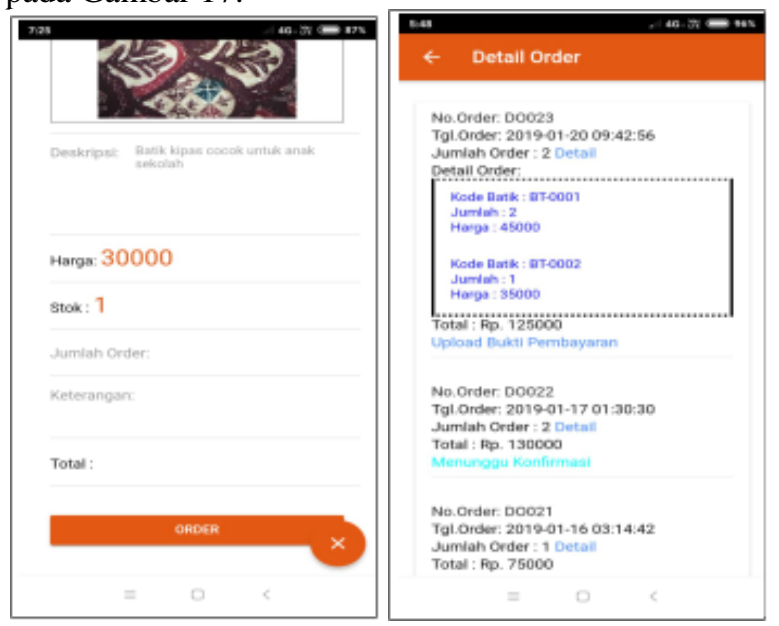

Gambar 17. Halaman Order Batik

Gambar 18 menunjukkan tampilan yang digunakan untuk menampilkan denah pelapak. Jika pengunjung/pembeli ingin mengunjungi secara langsung ke tempat pelapak, pengunjung/pembeli dapat melihat lokasi lokasi los/blok tempat pelapak berjualan dengan menekan tombol lokasi. Fasilitas ini dapat menghemat waktu pengunjung/pembeli yang ingin mencari lokasi pelapak penjual batik yang mereka inginkan. 


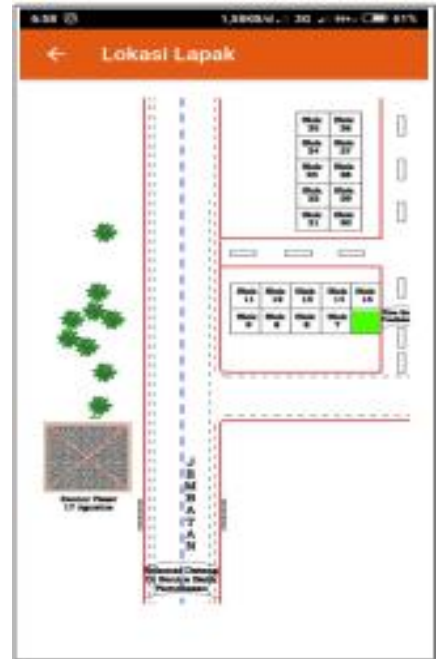

Gambar 18. Halaman Lokasi Pelapak

Selanjutnya untuk mengelola data batik dan melakukan transaksi jual beli, pelapak harus melakukan login terlebih dahulu. Jika login berhasil, pelapak dapat menambahkan data batik yaitu seperti kode batik, deskripsi, harga, jenis/motif, kondisi batik, stok, warna, dan gambar batiknya. Gambar 19 menunjukkan tampilan Form Tambah Data Batik.
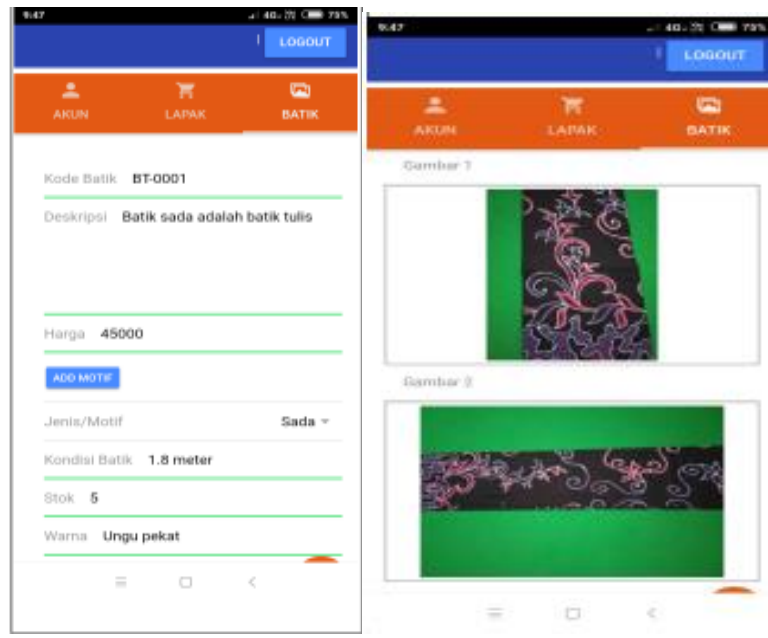

Gambar 19. Halaman Tambah Data Batik

Halaman Order Batik dari Pembeli merupakan halaman yang menunjukkan detail order batik dari pembeli yang meliputi tanggal, total order,detail kode batik yang dipesan, jumlah, harga dan catatan. Dari halaman ini pelapak bisa melakukan konfirmasi pembayaran dan mengirimkan pesan singkat kepada pembeli. Halaman ini ditunjukkan pada Gambar 20.

Aplikasi marketplace ini sudah diujicobakan kepada beberapa pelapak dan pengunjung/pembeli.
Menurut beberapa pelapak, dengan adanya aplikasi marketplace penjualan batik ini maka mereka masih bisa berjualan sekalipun tidak pergi atau berjualan ke pasar. Aplikasi ini juga dapat digunakan sebagai media promosi yang lebih luas tanpa dibatasi jarak. Sedangkan dari pihak pembeli, mereka sangat terbantu dengan katalog batik yang menampilkan berbagai macam batik dengan ragam motif, corak dan warna. Mereka juga bisa mengetahui harga dan ukuran batik sehingga tidak perlu pergi ke Pasar 17 Agustus Pamekasan. Selain itu adanya fasilitas pesan whatsapp sangat membantu untuk berkomunikasi dengan pelapak.

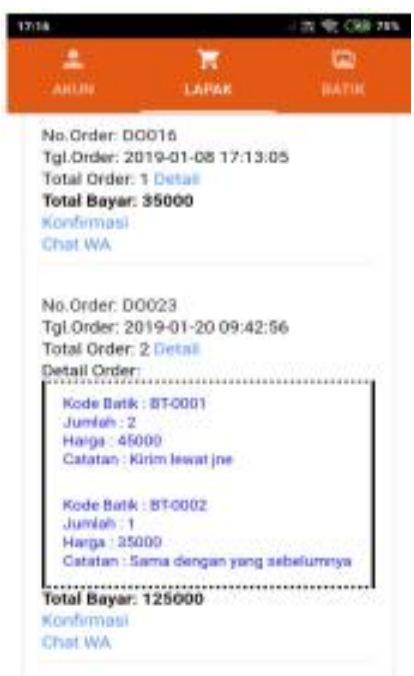

Gambar 20. Halaman Order Batik dari Pembeli

\section{Pengujian Sistem}

Selain melakukan wawancara, pengujian juga dilakukan dengan menggunakan System Usability Scale (SUS) dengan 10 responden yang terdiri dari 1 admin pasar, 3 pelapak dan 6 pengunjung/pembeli. Ada 10 instrumen pertanyaan dalam SUS dengan rentang jawaban 1 sampai dengan 5 [17]. Setelah dilakukan pencatatan semua jawaban, langkah selanjutnya adalah melakukan perhitungan dengan aturan sebagai berikut [19] :

1. Untuk nomor pertanyaan ganjil, skor pertanyaan dari skor pengguna dikurangi dengan $1(\mathrm{X}-1)$.

2. Untuk nomer pertanyaan genap, skor akhir didapat dari nilai 5 dikurangi skor pertanyaan yang didapat dari pengguna $(5-\mathrm{X})$.

Jumlahkan semua perolehan skor kemudian dikalian dengan 2,5. Nilai ini ada skor akhir dari SUS. Adapun untuk penelitian ini, hasilnya dapat dilihat pada Tabel 2. 
Tabel 2. Hasil Perhitungan SUS

\begin{tabular}{|c|c|c|c|c|c|c|c|c|c|c|c|}
\hline Responden & q1 & q2 & q3 & q4 & q5 & q6 & q7 & q8 & q9 & q10 & Skor \\
\hline 1 & 4 & 2 & 3 & 2 & 5 & 2 & 4 & 1 & 4 & 1 & 80,0 \\
\hline 2 & 3 & 2 & 4 & 3 & 5 & 3 & 4 & 1 & 4 & 3 & 70,0 \\
\hline 3 & 5 & 3 & 4 & 2 & 4 & 3 & 3 & 2 & 4 & 2 & 70,0 \\
\hline 4 & 4 & 2 & 3 & 1 & 4 & 2 & 4 & 1 & 4 & 1 & 80,0 \\
\hline 5 & 3 & 2 & 4 & 2 & 5 & 2 & 4 & 1 & 3 & 2 & 75,0 \\
\hline 6 & 5 & 3 & 3 & 3 & 4 & 3 & 4 & 2 & 4 & 3 & 65,0 \\
\hline 7 & 4 & 1 & 5 & 2 & 5 & 2 & 4 & 2 & 5 & 2 & 85,0 \\
\hline 8 & 4 & 1 & 3 & 2 & 4 & 2 & 3 & 1 & 4 & 2 & 75,0 \\
\hline 9 & 3 & 1 & 4 & 3 & 4 & 2 & 4 & 1 & 5 & 2 & 77,5 \\
\hline 10 & 4 & 2 & 5 & 3 & 5 & 3 & 4 & 2 & 4 & 2 & 75,0 \\
\hline \multicolumn{10}{|c|}{ Skata } \\
\hline \multicolumn{10}{|c|}{}
\end{tabular}

Dari rerata skor perhitungan SUS, maka rentang nilai pengujian [16,17] termasuk dalam Grade B yaitu layak untuk digunakan. Setelah dilakukan evaluasi dari jawaban koresponden, responden dari pelapak cenderung lebih mengalami kesulitan daripada pengunjung/penjual. Hal ini karena mereka rata-rata tidak terbiasa menggunakan aplikasi mobile seperti halnya pengunjung/penjual yang sudah terbiasa menggunakan marketplace.

\section{KESIMPULAN}

Aplikasi Marketplace Batik Madura ini sangat membantu seseorang jika ingin mencari dan membeli Batik Madura kapan saja dan di mana saja tanpa harus mengunjungi Pasar 17 Agustus Pamekasan. Selain itu dapat digunakan sebagai media memasarkan dan mempromosikan Batik Madura secara lebih luas. Adanya fasilitas pesan melalui Whatsapp, memudahkan pengunjung/pembeli berkomunikasi secara langsung dengan pelapak. Aplikasi ini juga dilengkapi dengan denah lokasi pelapak yang memudahkan pengunjung/pembeli untuk menemukan lokasi pelapak Batik Madura yang mereka cari.

Marketplace ini belum bisa menangani konfirmasi pembayaran otomatis, sehingga pembeli harus melakukan upload bukti pembayaran dan pelapak harus melakukan pengecekan. Penelitian selanjutnya dapat menambahkan fasilitas konfirmasi pembayaran secara otomatis. Selain itu dapat ditambah fasilitas jasa pengiriman sehingga memudahkan perhitungan ongkos kirim jika pembeli berasal dari luar kota

\section{UCAPAN TERIMA KASIH}

Terima kasih kepada Direktorat Riset dan Pengabdian kepada Masyarakat khususnya Direktorat Jenderal Penguatan Riset dan Pengembangan untuk bantuan dana penelitian sehingga penelitian ini terlaksana. Terima kasih juga kepada Kepala Pasar 17 Agustus Pamekasan yang memberi ijin untuk melakukan penelitian di area Sentra Batik Pasar 17 Agustus Pamekasan.

\section{DAFTAR PUSTAKA}

[1] U. Ubaidi and N. P. Dewi, "Voice pattern recognition using Mel-Frequency Cepstral Coefficient and Hidden Markov Model for bahasa Madura," J. Phys. Conf. Ser., vol. 1375, no. 1, pp. 1-6, 2019, doi: 10.1088/17426596/1375/1/012057.

[2] N. P. Dewi and Ubaidi, "Lexical Rule and Lexicon Effect for Part of Speech Tagging Bahasa Madura," J. Matrik, vol. 18, no. 1, pp. 65-72, 2018.

[3] B. Said and N. P. Dewi, "Implementation of Naïve Bayes updateable with modified absolute discount smoothing on Pamekasan Regent SMS center data classification," $J$. Phys. Conf. Ser., vol. 1375, no. 1, pp. 1-4, 2019, doi: 10.1088/1742-6596/1375/1/012029. [4] APJII, "Buletin APJII Edisi-40 2019," p. 6, 2019, [Online]. Available: https://apjii.or.id/survei.

[5] S. Palinggi and E. C. Limbongan, "Pengaruh Internet Terhadap Industri E-Commerce dan Regulasi Perlindungan Data Pribadi Pelanggan di Indonesia," Semin. Nas. Ris. dan Teknol., vol. 4, no. 1, pp. 225-232, 2020, [Online]. Available:

http://www.proceeding.unindra.ac.id/index.ph p/semnasristek2020/article/view/2543.

[6] E. Turban, D. King, J. K. Lee, T.-P. Liang, and D. C. Turban, Electronic Commerce - A Managerial and Social Perspective. 2015.

M. Septianto, S. F. S. Gumilang, and F. M. Al Anshary, "Perancangan Dan Pengembangan Marketplace Jual Beli Buku Bekas Pada Startup Gebbuk Berbasis Mobile," $e$ Proceeding Eng., vol. 5, no. 2, pp. 3335-3345, 2018.

[8] A. Syahab, "Analisis Sistem E-Commerce Pada Perusahaan Marketplace Mobile Shopee Indonesia," in Seminar Nasional Sistem Informasi dan Teknologi Informasi (SENSITEK), 2018, pp. 565-569.

[9] H. Heriyanto et al., "Aplikasi Online 
Marketplace pada PT . XYZ di Surabaya," J. Infra, vol. 4, no. 2, pp. 183-188, 2016.

[10] J. Zhang, M. X. Cai, T. Lu, X. H. Sun, and J. L. Jia, "Lumbar spinal stenosis treated with polyetheretherketone pedicle screw fixation combined with interbody fusion: A follow-up assessment focusing on bone fusion rate," Chinese J. Tissue Eng. Res., vol. 20, no. 12, pp. 1684-1689, 2016, doi: 10.3969/j.issn.2095-4344.2016.12.002.

[11] M. I. Kurniawan, B. Priyambadha, and A. A. Soebroto, "Pengembangan Aplikasi Marketplace Untuk Jasa Konfeksi," J. Pengemb. Teknol. Inf. dan Ilmu Komput., vol. 3, no. 8, pp. 7391-7398, 2019.

[12] R. Fauzi, S. Wibowo, and D. Y. Putri, "Perancangan Aplikasi Marketplace Jasa Percetakan Berbasis Website," Fountain Informatics $J$., vol. 3, no. 1, p. 5, 2018, doi: 10.21111/fij.v3i1.1824.

[13] H. Himawan, A. Saefullah, and S. Santoso, "Analisa dan Perancangan Sistem Informasi Penjualan Online (E-Commerce) pada CV Selaras Batik Menggunakan Analisis Deskriptif," Sci. J. Informatics, vol. 1, no. 1, pp. 53-63, 2015, doi: 10.15294/sji.v1i1.3641.

[14] B. K. Riasti, S. A. T. Bawono, and E. Setyawan, "E-Marketplace Batik," Indones. J. Appl. Informatics, vol. 1, no. 1, p. 45, 2016, doi: 10.20961/ijai.v1i1.8390.

[15] I. Darmawan, W. Puspitasari, and R. Andreswari, "Pemanfaatan E-Commerce
Dalam Peningkatan Pemasaran di UMKM Grosir Batik Tasikmalaya," Charity, vol. 2, no. 1, pp. 0-3, 2019, doi: 10.25124/charity.v2i1.2069.

[16] R. Baxter, Software engineering is software engineering. 2006.

[17] N. P. Dewi and I. Listiowarni, "Implementasi Game Based Learning pada Pembelajaran Bahasa Inggris," J. RESTI (Rekayasa Sist. dan Teknol. Informasi), vol. 3, no. 2, pp. 124-130, 2019, doi: 10.29207/resti.v3i2.885.

[18] A. Holzer and J. Ondrus, "Mobile application market: A developer's perspective," Telemat. Informatics, vol. 28, no. 1, pp. 22-31, 2011, doi: 10.1016/j.tele.2010.05.006.

[19] D. W. Ramadhan, "PENGUJIAN USABILITY WEBSITE TIME EXCELINDO MENGGUNAKAN SYSTEM USABILITY SCALE (SUS) (sTUDI KASUS: WEBSITE TIME EXCELINDO)," JIPI (Jurnal Ilm. Penelit. dan Pembelajaran Inform., vol. 4, no. 2, p. 139, 2019, doi: 10.29100/jipi.v4i2.977.

[20] U. Ependi, F. Panjaitan, and H. Hutrianto, "System Usability Scale Antarmuka Palembang Guide Sebagai Media Pendukung Asian Games XVIII," J. Inf. Syst. Eng. Bus. Intell., vol. 3, no. 2, p. 80, 2017, doi: 10.20473/jisebi.3.2.80-86.

[21] F. F. Laksana and S. Suyoto, "Pengukuran Kualitas Ux Website Menggunakan Sus," Comput. Eng. Sci. Syst. J., vol. 4, no. 2, p. 138, 2019, doi: 10.24114/cess.v4i2.12928. 